\title{
Persistence of Low Pathogenic Avian Influenza Virus in Waterfowl in a southern African Ecosystem
}

\author{
Alexandre Caron ${ }^{1,2,3}$, Celia Abolnik ${ }^{4}$, Josphine Mundava ${ }^{5}$, Nicolas Gaidet ${ }^{2}$, Chistina E. Burger ${ }^{4}$, \\ Bontsi Mochotlhoane $^{4}$, Leo Bruinzeel ${ }^{6,7}$, Ngoni Chiweshe ${ }^{1}$, Michel de Garine-Wichatitsky ${ }^{1,2}$, \\ Graeme S. Cumming ${ }^{6}$
}

\section{Authors' affiliations:}

${ }^{1}$ UPR AGIRs, Department ES, Cirad, Harare, Zimbabwe

${ }^{2}$ UPR AGIRs, Department ES, Cirad, Montpellier, France

${ }^{3}$ Mammal Research Institute, Department of Zoology and entomology, Uni. of Pretoria

${ }^{4}$ ARC-Onderstepoort Veterinary Institute, Pretoria, South Africa

${ }^{5}$ Forestry Resources and Wildlife Management, National University of Science and

Technology, Bulawayo, Zimbabwe

${ }^{6}$ Percy FitzPatrick Institute, DST/NRF Centre of Excellence, University of Cape Town, Rondebosh, South Africa

${ }^{7}$ Altenburg \& Wymenga Ecological Consultants, Veenwouden, the Netherlands

\begin{abstract}
Waterfowl were counted and sampled in a Zimbabwean wetland over 24 months. LPAI strains were detected during 20 consecutive months, providing the first evidence of regional yearly persistence of LPAI. We discuss the role of Afro-tropical ducks in viral maintenance and transmission and attempt to explain the observed patterns.
\end{abstract}

Keywords: Avian Influenza, waterfowl, Africa 
Text: Low Pathogenic Avian Influenza (LPAI) viruses in the Northern Hemisphere are maintained by their waterfowl reservoirs - mainly Anseriformes - and the environment (Webster et al. 1992; Olsen et al. 2006). Waterfowl can provide a source of LPAI strains for domestic avian populations, in which they can evolve into Highly Pathogenic AI (HPAI) (Abolnik et al. 2007; Abolnik et al. 2009; Caron et al. 2009). Previous studies have established the presence of LPAI in paleartic migrants and afro-tropical birds in Africa, but no maintenance mechanism has been described (Abolnik et al. 2006; Gaidet et al. 2006). A priori, the high temperatures experienced by afro-tropical regions should decrease the potential survival of the virus in the environment and hence prevent the persistence of LPAI throughout the year (Brown et al. 2009). In this study we present results from a longitudinal survey of LPAI in waterfowl conducted in Zimbabwe in 2007-2009 to test their potential persistence in an African ecosystem.

The study was undertaken in the Manyame catchment (30³0’30’’, 1745`), 35 kilometers West of Harare, on two adjacent lakes (Lake Chivero and Manyame, 65 and $185 \mathrm{~km}^{2}$ respectively)(Figure 1). Both lakes are important waterfowl habitats in Zimbabwe. Although paleartic Anseriformes seldom reach this area during their migration, it hosts a range of other paleartic waterbirds as well as passerines and raptors during September-April (Figure 2a). In addition, Afro-tropical nomadic and resident species inhabit these lakes. Waterfowl were counted and captured every two months between May 2007 and March 2009, resulting in 12 count and capture sessions encompassing 2 years. Fifteen representative sites were selected using local ornithological expertise (Figure 1). For each session, 4 point counts were done in each site at different times of day. Counts lasted half an hour and included all birds within a 150m radius. After a week of site preparation (baiting), captures were performed during a week in suitable counting sites using baited walk-in traps and mist-nets. For each bird captured, cloacal and 
tracheal swabs were collected, placed in viral transport medium (phosphate-buffered saline/glycerol/ antibiotics), and transported in liquid nitrogen prior to testing. RNA was extracted using the MagNaPure LC total nucleic acid isolation kit-high performance (Roche, Mannheim, Germany) on a MagNAPure robot (Roche). Real-time reverse transcription PCR was performed using the VLA TaqMan ${ }^{\circledR}$ Influenza A/H5/H7 Detection Kits (Applied Biosystems) on either a StepOnePlus (Applied Biosystems) or a Light Cycler 480 (Roche) platform. Positive samples were inoculated into embryonating fowls' eggs for virus isolation according to standard procedures (OIE 2008).

A total of 1601 waterbirds were captured. The number of birds captured averaged 133 per session (with a minimum of 61 and a maximum of 247) (Figure 2b). These captures represented 96 species. Anseriformes constituted $46.8 \%$ of captures, and were dominated by 2 species, viz. Anas erythrorhyncha (red-billed teal, 66.5\%) and Dendrocygna viduata (white-faced whistling duck, 26.9\%). The composition of bird sampled per order is reported in Table 1.

This is the first report of the persistence of LPAI strains over a year in waterfowl in an African wetland. LPAI strains were detected in the waterfowl community during 10 consecutive sessions over a period of 20 months with a prevalence ranging from 1.3-22.3\% (Figure 2c). Of 2791 (51.1\% cloacal, 48.9\% tracheal) test results, 100 samples were positive for the presence of RNA of the influenza A virus group (95 birds, 5.9\% of total of birds), $9(0.6 \%)$ and $10(0.6 \%)$ were positive for the $\mathrm{H} 5$ and $\mathrm{H} 7$ subtype respectively (Table 2). $49.5 \%$ of positive birds were ducks, of which 93.7\% were Anas erythrorhyncha (Anatidae) or Dendrocygna viduata (Dendrocygnidae). 
Global prevalence per session varied between 0.0 and 22.3\% across species and between 0.0 and 20.0\% for Anseriformes (Figure 2c). No viruses could be isolated.

In both years, viruses were detected in the waterbird community during the period when paleartic birds are absent or rare (May-July sessions). This result suggests the yearly persistence of LPAI in Afro-tropical waterfowl and raises the hypothesis of an endemic cycle in Zimbabwe or at least in Southern Africa. However, Table 2 indicates higher prevalence when the paleartic birds are present in the ecosystem (mainly from September to January) compared to when there are absent (May to July). Therefore, AI viruses (AIV) appear to be present all year long, although we cannot exclude the necessity of seasonal introduction of AIV by paleartic birds in September to maintain the cycle. Observing viral persistence, we cannot prove maintenance of LPAI in this ecosystem.

The detection of subtypes H5, H7 and other influenza A viruses (subtypes undetermined) in ducks indicates the simultaneous circulation of multiple subtypes. The H7 subtype was detected during 14 consecutive months, although not for each session (4 out of 12 sessions) during both dry and wet season and on two consecutive years. From these data one cannot deduce that the H7 or $\mathrm{H} 5$ subtypes detected in subsequent years were related. However, the results do suggest that, at least for some subtypes, some strains may be maintained throughout the year and between years. The H5 subtype was detected only during the January 2008 session (Table 3) but in a relatively high prevalence: $\mathrm{H} 5$ does not appear to be a common $\mathrm{H}$ subtype in waterbird communities (Krauss et al., 2004; Wallensten et al. 2007).

The high prevalence that we observed during the 2007 hot-dry season (September-November) and beginning of the rainy season (January 2008) is comparable to the prevalence level reported in sites in the Northern hemisphere during fall migration (September)(Krauss et al. 2004; 
Wallensten et al. 2007). The seasonal variations in prevalence have to be interpreted with caution as the sample composition in species and abundance varied between sessions, due to capture bias (Figure 2b). For example, January 2008 and 2009 report the highest and lowest densities both with small sample size. However the profile of Anseriformes' prevalence (controlling for part of this bias) is similar in trends and intensity to global prevalence. A small sample size of ducks was always associated with small numbers of ducks counted (Figure 2a, b). During the hot-dry season, ducks tend to concentrate in lakes and these flocks provide ample opportunity for disease transmission. During the rainy season (December-Mars), ducks tend to disperse out of the study lakes to breed; our sample size reflects these movements. During the first rainy season (January 2008), viruses were circulating despite few ducks in the system (4 ducks out of 27 positive birds), suggesting a complementary role of local and paleartic Charadriiformes and Passeriformes in the persistence process (Table $1 \& 3$ ).

Environmental conditions in this ecosystem (1500m altitude and an average annual temperature of $17.9^{\circ} \mathrm{C}$ ) are typical of Eastern and Southern African highveld and could be compatible with virus survival in the water (Stallknecht et al. 1990). We failed to detect any positive samples during the 2009 rainy season. This result may be explained by a small sample size or by the nonpersistence of LPAI strains in this ecosystem. The observed concentration of afro-tropical ducks on the lake shores during the hot-dry season is driven by a combination of increased resource availability on receding lake shores (Figure 2a), the complete drying-up of non-perennial wetlands leaving in the ecosystem a few water bodies to be occupied by the same bird community, and the need for the birds to undergo flightless moult in a deepwater location. This influx of waterbirds into the ecosystem offers numerous opportunities for viral introductions from other African regions (afro-tropical nomadic species) or from Eurasia (paleartic 
migrants)(Abolnik et al. 2006). In addition, this concentration of hosts during the hot-dry season when the viruses should have the lowest survival in the environment may contribute to viral maintenance: the high density of birds provides higher host availability and higher rate of contact between hosts, decreasing the time necessary for successful fecal-oral transmission. The seasonal aggregation of ducks in the Manyame catchment could explain the higher prevalence observed during the first hot-dry and early rainy season. The combination of favorable environmental conditions during particular seasons (rainy and dry-cold season) and the presence of paleartic birds and high duck density during harsh season (hot-dry) could support a persistence or maintenance hypothesis in this ecosystem, although we cannot resolve the effects of specific factors. Environmental transmission has been shown to play an important role in viral persistence in stochastic models of disease transmission (Breban et al. 2009; Rohani et al. 2009).

The observed inter-annual variation (including the non-persistence in 2009) could be explained by variability in environmental factors. Rainfall determines lake levels and triggers a differential waterfowl concentration during the following hot-dry season. This hypothetical relation can be observed in Figure 2a: a low lake level is associated with a high bird concentration in 2007, in contrast to 2008. Viral persistence (driven by host availability and susceptibility) could thus be dependent on waterfowl density. Our data could be interpreted as showing that during the hot-dry season of 2008, the threshold density was not reached and the LPAI did not persist.

In conclusion, our data suggest the persistence of multiple AIV strains in the waterfowl community of a Zimbabwean ecosystem for 20 consecutive months. The persistence of LPAI in an African ecosystem indicates that the role of afro-tropical ducks in LPAI epidemiology requires further assessment. This study suggests that African ecosystems are not merely passive receptors of AIV from Eurasia. African waterfowl communities have the potential to harbor multiple viral 
strains for an extended period, indicating that they play a broad-scale role in the epidemiology of AIV. The recent detection in Nigeria of HPAI H5N2 in apparently healthy waterfowl (including Dendrocygna viduata) reinforces this hypothesis (Gaidet et al. 2008) with phylogenetic data linking this strain to European and African waterfowl . A relation between environmental determinants, host community ecology and virus ecology is presented with potential for a predictive approach. These observations are particularly relevant for animal and public health at the wildlife/domestic/human interface in two contexts: (a) in Africa, where HPAI H5N1 is recurring in domestic poultry production systems (Ducatez et al. 2007; Cattoli et al. 2009) (providing opportunities for recombination with local LPAI), veterinary/public health sectors may be weak, and the wild/domestic bird interface is rarely monitored or controlled despite a predicted risk (Kilpatrick et al. 2006); and (b) in Eurasia, since the spring migration of paleartic birds can theoretically expose Eurasian ecosystems to LPAI strains from Africa (although thus far, with little information available, no genes of African origin have been detected in the Eurasian viral pool) (Abolnik et al. 2006; Abolnik 2007). 


\section{References}

Abolnik C (2007). Detection of a North American lineage H5 avian influenza virus in a South African wild duck. Onderstepoort Journal of Veterinary Research 74:177-180.

Abolnik C, Bisschop S, Gerdes T, Olivier A, and Horner R (2007). Outbreaks of avian influenza H6N2 viruses in chickens arose by a reassortment of H6N8 and H9N2 ostrich viruses. Virus Genes 34:37-45.

Abolnik C, Cornelius E, Bisschop SPR, Romito M, and Verwoerd D (2006). Phylogenetic Analyses of genes from South Africa LPAI Viruses isolated in 2004 from Wild Aquatic Birds suggests Introduction by Eurasian migrants. OIE/FAO International Scientific Conference on Avian Influenza, Basel, Karger

Abolnik C, Londt BZ, Manvell RJ, Shell W, Banks J, Gerdes GH, et al. (2009). Characterisation of a highly pathogenic influenza A virus of subtype H5N2 isolated from ostriches in South Africa in 2004. Influenza Other Respi Viruses 3:63-68.

Breban R, Drake JM, Stallknecht DE, and Rohani P (2009). The role of environmental transmission in recurrent avian influenza epidemics. PLoS Comput Biol 5:e1000346.

Brown JD, Goekjian G, Poulson R, Valeika S, and Stallknecht DE (2009). Avian influenza virus in water: Infectivity is dependent on $\mathrm{pH}$, salinity and temperature. Vet Microbiol 136:2026.

Caron A, Gaidet N, de Garine-Wichatitsky M, Morand S, and Cameron EZ (2009). Evolutionary biology, community ecology and avian influenza research. Infection, Genetics and Evolution 9:298-303.

Cattoli G, Monne I, Fusaro A, Joannis TM, Lombin LH, Aly MM, et al. (2009). Highly pathogenic avian influenza virus subtype H5N1 in Africa: a comprehensive phylogenetic analysis and molecular characterization of isolates. PloS ONE 4:e4842.

Ducatez MF, Olinger CM, Owoade AA, Tarnagda Z, Tahita MC, Sow A, et al. (2007). Molecular and antigenic evolution and geographical spread of H5N1 highly pathogenic avian influenza viruses in western Africa. J Gen Virol 88:2297-2306.

Gaidet N, Cattoli G, Hammoumi S, Newman SH, Hagemeijer W, Takekawa JY, et al. (2008). Evidence of Infection by H5N2 Highly Pathogenic Avian Influenza Viruses in Healthy Wild Waterfowl. PLoS Pathogens 4:e1000127.

Gaidet N, Dodman T, Caron A, Balança G, Desvaux S, Goutard F, et al. (2006). Influenza A viruses in waterbirds in Africa. Emerg Infect Dis 13:626-629.

Kilpatrick AM, Chmura AA, Gibbons DW, Fleischer RC, Marra PP, and Daszak P (2006). Predicting the global spread of H5N1 avain influenza. Proc Natl Acad Sci U S A 103:19368-19373.

Krauss S, Walker D, Pryor SP, Niles L, Chenghong L, Hinshaw VS, et al. (2004). Influenza A viruses of migrating wild aquatic birds in North America. Vector Borne Zoonotic Dis 4:177-189.

OIE (2008). Avian Influenza. Pages 1-20 in OIE, editor. Manual of Diagnostic Tests and Vaccines for Terrestrial Animals OIE, Paris, France.

Olsen B, Munster VJ, Wallensten A, Waldenstrom J, Osterhaus AD, and Fouchier RA (2006). Global patterns of influenza a virus in wild birds. Science 312:384-388.

Rohani P, Breban R, Stallknecht DE, and Drake JM (2009). Environmental transmission of low pathogenicity avian influenza viruses and its implications for pathogen invasion. Proc Natl Acad Sci U S A 106:10365-10369. 
Stallknecht DE, Kearney MT, Shane SM, and Zwank PJ (1990). Effects of pH, temperature, and salinity on persistence of avian influenza viruses in water. Avian Dis 34:412-418.

Wallensten A, Munster VJ, Latorre-Margalef N, Brytting M, Elmberg J, Fouchier RA, et al. (2007). Surveillance of Influenza A Virus in Migratory Waterfowls in Norhtern Europe. Emerg Infect Dis 13:404-411.

Webster RG, Bean WJ, Gorman OT, Chambers TM, and Kawaoka Y (1992). Evolution and Ecology of Influenza A Viruses. Microbiological Reviews 56:152-179. 
Table 1: Sample size per session and proportion of swab sampled per order. The second row indicates the number of swabs (cloacal or tracheal) tested per session. The following rows indicate percentage of swab belonging to different bird order.

Table 2: Prevalence (prev; in percent), sample size (n) for the entire birds sampled (All birds) and only the ducks sampled (Ducks Only) compared between sessions when paleartics birds are present in the ecosystem (September to March) and absent (May to July). Results for Chi-2 test and level of significance, testing the null hypothesis H0: Prev(MayJuly)=Prev(Sept-Mar).

Table 3: PCR positive swabs for Avian Influenza and hemagglutinase type when available. The second row indicates the number of swabs positive per session. The following rows indicate the number of swabs tested PCR positive for Avian Influenza: the hemagglutinase type is determined (H5 or H7) or not available (na).

Figure 1: Counting and capture sites (red dots) in Manyame (left) and Chivero (right) lakes with location of the ecosystem in Zimbabwe (light grey areas represent national parks of Zimbabwe) and of Zimbabwe in Africa. Lakes satellite pictures obtained through Google Earth database (® Google Earth).

Figure 2: (a) Birds counted per session: in black duck species, in light grey paleartic migrants and in dark grey other species; the solid line (linked to the right vertical axis) represent the variations of the lake level; (b) birds captured per session: in black duck species, in light grey paleartic migrants and in dark grey other species; (c) global (black dots) and duck 
(white dots) prevalence per session with confidence interval. An indication of the seasons in this ecosystem is given in blocks and the period when paleartic migrants are present in the system is also presented. 
Table 1:

\begin{tabular}{|c|c|c|c|c|c|c|c|c|c|c|c|c|c|}
\hline & May-07 & Jul-07 & Sep-07 & Nov-07 & Jan-08 & Mar-08 & May-08 & Jul-08 & Sep-08 & Nov-08 & Jan-09 & Mar-09 & Total \\
\hline Swab results $(c+t)$ & $n=200$ & $n=279$ & $n=414$ & $n=161$ & $n=227$ & $n=163$ & $n=216$ & $n=218$ & $n=271$ & $n=356$ & $n=194$ & $n=92$ & $n=2791$ \\
\hline Anseriformes & 66.0 & 87.8 & 79.0 & 79.5 & 16.3 & 37.4 & 59.3 & 41.3 & 16.6 & 33.7 & 5.7 & 22.8 & 48.2 \\
\hline Charadriiformes & 29.0 & 10.8 & 19.1 & 17.4 & 60.4 & 27.6 & 16.7 & 43.6 & 52.0 & 48.3 & 67.5 & 33.7 & 35.2 \\
\hline Passeriformes & 1.0 & 0.7 & 1.4 & 0.6 & 16.3 & 26.4 & 10.2 & 9.2 & 17.7 & 12.4 & 7.2 & 8.7 & 8.8 \\
\hline Columbiformes & 0.0 & 0.7 & 0.0 & 0.0 & 0.0 & 2.5 & 4.6 & 3.2 & 3.0 & 1.4 & 9.8 & 10.9 & 2.3 \\
\hline Coraciiformes & 1.0 & 0.0 & 0.0 & 1.2 & 6.6 & 3.7 & 3.7 & 0.0 & 5.2 & 1.1 & 1.0 & 10.9 & 2.3 \\
\hline Ciconiiformes & 1.0 & 0.0 & 0.0 & 0.0 & 0.4 & 1.2 & 0.9 & 0.0 & 4.8 & 2.2 & 6.7 & 8.7 & 1.8 \\
\hline Divers & 2.0 & 0.0 & 0.5 & 1.2 & 0.0 & 1.2 & 4.6 & 2.8 & 0.7 & 0.8 & 2.1 & 4.3 & 1.4 \\
\hline
\end{tabular}


Table 2:

\begin{tabular}{r|rr|rr|rr}
\hline & May-July & \multicolumn{3}{|c|}{ Sept-Mar } & & \\
\hline & prev & $\mathrm{n}$ & prev & $\mathrm{n}$ & Chi-2 & $\mathrm{p}$ \\
\hline All birds & 2,63 & 494 & 7,23 & 1106 & 13,19 & $<0,001^{*}$ \\
Ducks Only & 3,76 & 319 & 8,14 & 430 & 5,94 & $<0,01^{*}$ \\
\hline
\end{tabular}


Table 3:

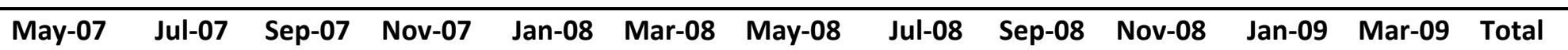

\begin{tabular}{|c|c|c|c|c|c|c|c|c|c|c|c|c|c|}
\hline Swab positive & $p=5$ & $p=2$ & $p=26$ & $p=5$ & $p=34$ & $p=4$ & $p=4$ & $p=2$ & $p=2$ & $p=16$ & $p=0$ & $p=0$ & $p=100$ \\
\hline Anseriformes & $\begin{array}{l}4 * \text { na } \\
1 * \mathrm{H} 7\end{array}$ & $2 *$ na & $\begin{array}{r}17 * \text { na } \\
2 * \mathrm{H} 7\end{array}$ & $5 *$ na & $\begin{array}{l}3 * \text { na } \\
3 * \text { H5 }\end{array}$ & $2 *$ na & $4 * \mathrm{H} 7$ & $2 *$ na & $1 *$ na & $3 *$ na & 0 & 0 & $\begin{array}{r}39 * \text { na } \\
3 * \mathrm{H} 5 \\
7 * \mathrm{H} 7\end{array}$ \\
\hline Charadriiformes & 0 & 0 & $\begin{array}{l}5 * \text { na } \\
1 * \mathrm{H} 7\end{array}$ & 0 & $\begin{array}{r}14 * \text { na } \\
4 * \mathrm{H} 5 \\
2 * \mathrm{H} 7\end{array}$ & $2 *$ na & 0 & 0 & 0 & $8 *$ na & 0 & 0 & $\begin{array}{r}29 * \text { na } \\
4 * \mathrm{H} 5 \\
3 * \mathrm{H} 7\end{array}$ \\
\hline Passeriformes & 0 & 0 & $1 *$ na & 0 & $\begin{array}{l}5^{*} \text { na } \\
1 * \mathrm{H} 5\end{array}$ & 0 & 0 & 0 & $1 *$ na & 5*na & 0 & 0 & $\begin{array}{r}12 * \text { na } \\
1 * \mathrm{H} 5\end{array}$ \\
\hline Coraciiformes & 0 & 0 & 0 & 0 & $\begin{array}{l}1 * \text { na } \\
1 * \mathrm{H} 5\end{array}$ & 0 & 0 & 0 & 0 & 0 & 0 & 0 & $\begin{array}{l}1 * \text { na } \\
1 * \mathrm{H} 5\end{array}$ \\
\hline
\end{tabular}


Figure 1:

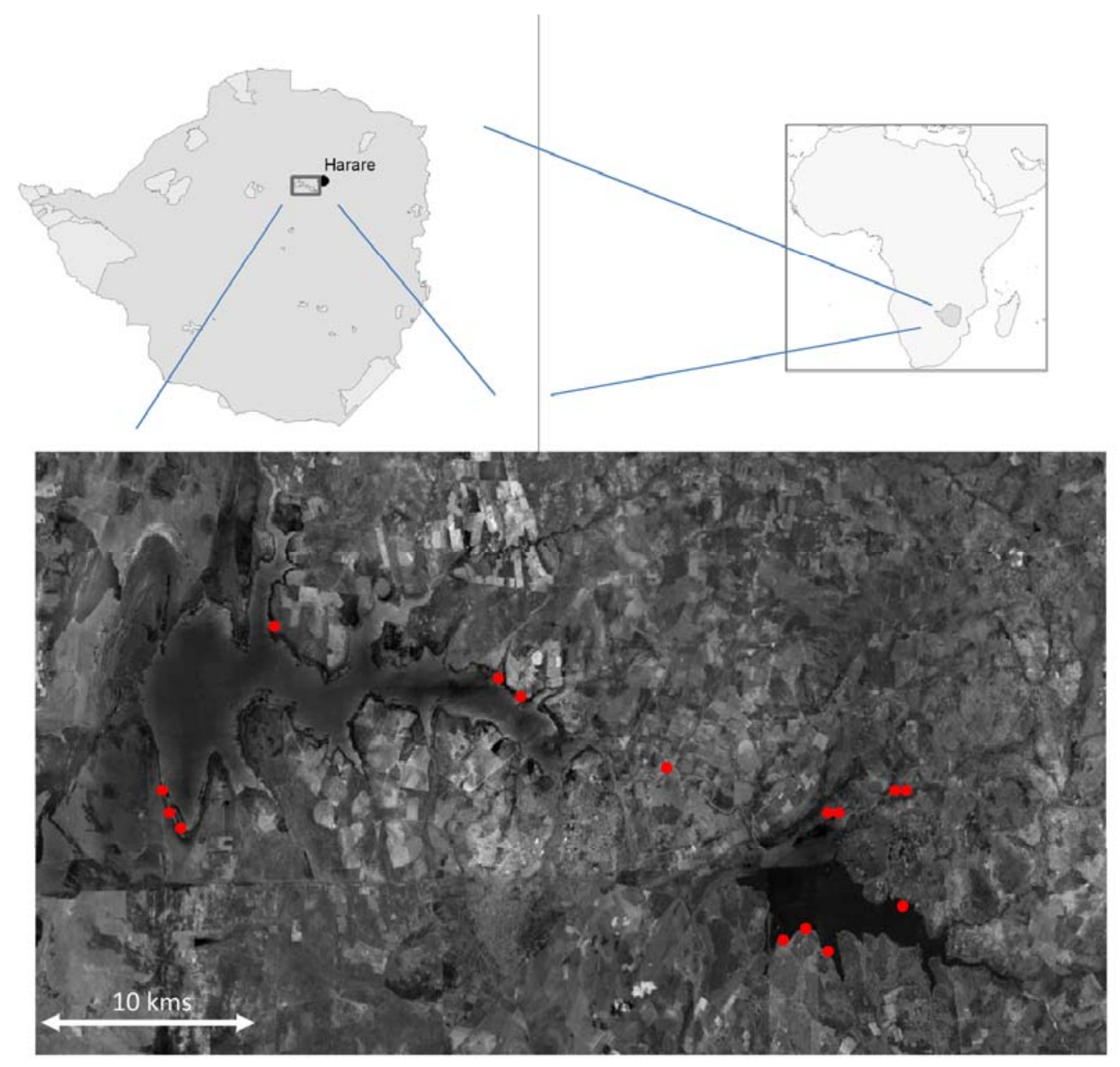


Figure 2:
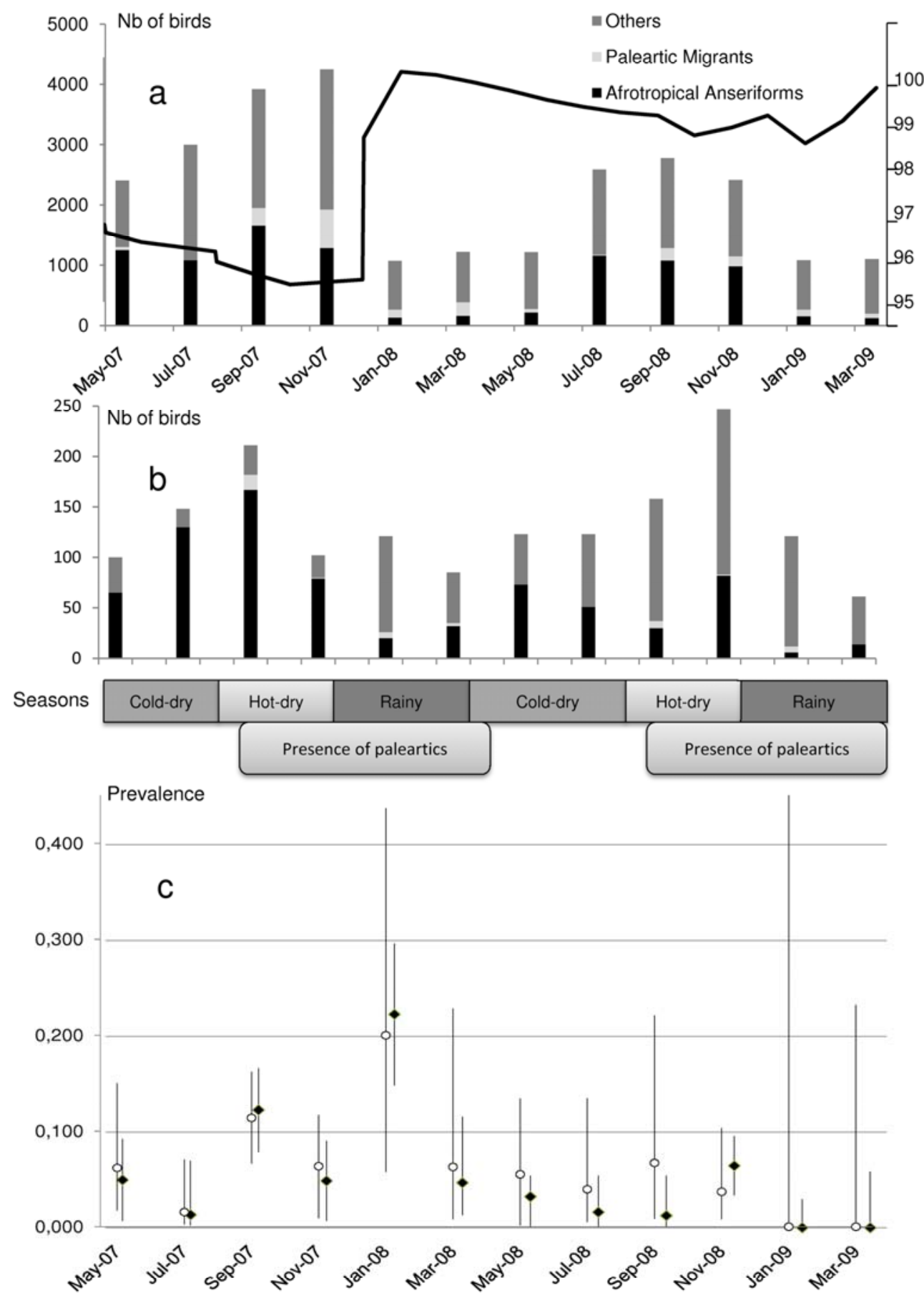